\title{
New Neotropical species of the genus Austrotinodes Schmid (Trichoptera: Ecnomidae)
}

\author{
ROBIN E. THOMSON \& RALPH W. HOLZENTHAL \\ Department of Entomology, University of Minnesota, 219 Hodson Hall, 1980 Folwell Avenue, St. Paul, Minnesota, 55108, U.S.A. \\ E-mail: thom1514@umn.edu; holze001@umn.edu
}

\begin{abstract}
Six new species of Austrotinodes Schmid (Trichoptera: Ecnomidae) from the Neotropics are described: A. abrachium (Brazil), A. belchioris (Brazil), A. boliviensis (Bolivia), A. cressae (Venezuela), A. longispinum (Brazil), and A. taquaralis (Brazil). Illustrations of male genitalia are provided. These additions bring the total world fauna of Austrotinodes to 55 species.
\end{abstract}

Key words: Trichoptera, caddisflies, Austrotinodes, new species, Neotropical

\section{Introduction}

Schmid (1955) established the genus Austrotinodes to accommodate 2 new species from Chile; 2 species previously described by Navás (1934) were also included. In 1973, Flint reviewed the genus and described 4 new species, including new records from Mexico and Central America. Flint \& Denning (1989) also reviewed the genus, providing new records from Costa Rica, and described 14 new species from elsewhere in the Neotropics. Bowles (1995) described the first species from the United States. Additional species descriptions and distributions have been provided by Schmid (1958, 1964), Flint (1969, 1983, 1996), Kumanski (1987), Botosaneanu (1990), Muñoz-Quesada \& Holzenthal (1993), Angrisano (1994), and Flint \& Sykora (2004). Up to and including Flint \& Sykora (2004), Austrotinodes had only been recorded in the Neotropical or southern Nearctic biogeographic regions. Cartwright (2009) recorded the genus for the first time in Australia and described 11 new species, bringing the total world fauna to 49 species. Of the 11 Australian species, 4 display close similarities with some of the Neotropical species, including the type species, A. latior Schmid; these similarities may be indicative of a Gondwanan origin (Cartwright 2009). In a recent phylogenetic analysis (Johanson \& Espeland 2009), Austrotinodes was consistently monophyletic within the family Ecnomidae. In this paper, we describe 6 new species from Bolivia, Brazil, and Venezuela.

Larvae have been collected in deep pools with coarse substrate, but most likely are tube-dwellers occurring in the sand or gravel of stream bottoms or on rocks and large boulders (Flint 1973, Bowles 1995). Larvae construct elongate, flimsy tubes composed of sand, rock fragments and silk (Flint 1973, Wiggins 1996). Larval foods are unknown (Flint et al. 1999). Prepupae and pupae have been collected on the underside of rocks in riffles or sandy rocky streams (Flint 1973).

Morphological terminology used for male genitalia follows that of Flint \& Denning (1989). For simplicity, paired structures are discussed in the singular. Procedures for specimen preparation followed those explained in detail by Blahnik et al. (2007). For specimen examination and illustration, cleared genitalia were placed in a watch glass with glycerin and a small amount of cotton. Cotton strands held the genitalia in place and allowed structures to be viewed in precise lateral, dorsal, ventral, and caudal positions. Genitalia were examined with an Olympus BX41 compound microscope at 250-500 X magnification. Structures were traced in pencil with the use of a camera lucida (drawing tube) mounted on the microscope. Pencil sketches were then scanned (Fujitsu ScanSnap S1500M scanner), edited in Adobe Photoshop (v. 9.0.2, Adobe Systems Inc.), 
and used as a template in Adobe Illustrator (v. 13.0.2, Adobe Systems Inc.) in order to be digitally inked. Electronic "drawing" was completed with the aid of a graphics tablet (Bamboo Fun, Wacom Company, Limited). Species descriptions were constructed using the program DELTA (Dallwitz et al. 1999 onwards) and specimen management followed the procedures outlined by Holzenthal \& Anderson (2004). Each specimen examined during the study was affixed with a barcode label (4 mil polyester, $8 \times 14 \mathrm{~mm}$, code 49) bearing a unique alphanumeric sequence beginning with the prefix UMSP. The prefix is not meant to imply ownership by the University of Minnesota Insect Collection (UMSP), but only to indicate that the specimen was databased at that collection. Information regarding specimens examined for this study, including taxonomic, locality, collection, storage and individual specimen barcode information can be accessed at the UMSP Trichoptera Biota database <www.entomology.umn.edu/museum.databases/BIOTAdatabase.html>. Types of species described and other material examined are deposited in the University of Minnesota Insect Collection, St. Paul, Minnesota (UMSP); the Museu de Zoologia, Universidade de São Paulo, Brazil (MZUSP); the Museo de Historia Natural Noel Kempff Mercado, Santa Cruz de la Sierra, Bolivia (UASC); and the National Museum of Natural History, Smithsonian Institution, Washington, D.C. (NMNH).

\section{Descriptions}

\section{Austrotinodes abrachium, new species}

Fig. 1

Diagnosis. This species is most similar to A. belchioris, new species, and A. taquaralis, new species, differing in its lack of an intermediate appendage. In A. abrachium, the phallic guide is elevated higher over the inferior appendage than in either A. belchioris or A. taquaralis. In A. brachium, the phallic guide is pointed in caudal view, while in $A$. belchoris and $A$. taquaralis it has a single indentation.

Description. Male. Forewing length $4.3 \mathrm{~mm}(\mathrm{n}=1)$. Body sclerites brown, dorsum of head unknown, head missing; thorax light brown with pale yellow and light brown setae dorsally, light brown ventrally; leg segments with brown setae. Forewings covered with fine pale yellow setae with small scattered patches of light brown setae. Genitalia. Segment IX deeply divided, sternum elongated; in lateral view, enlarging medially, ventral margin slightly curved apically; in ventral view, apical margin convex. Phallic guide sclerotized, elevated over inferior appendages; in lateral view, base narrow, apex pointed, reaching middle of inferior appendage; in caudal view, pointed. Inferior appendages fused mesally, attached apicomesally on sternum IX; in lateral view, subquadrate; in ventral view, lateral lobes ovate, directed posterolaterally, posterior margin concave with central point. Tergum $X$ divided into pair of semimembranous oval lobes, separated by deep emargination, bearing dorsal setae. Preanal appendage long, surface setose, margin smooth, widest basally, narrowing apically, apex acute. Intermediate appendage absent. Phallus with sclerotized phallobase and membranous apical region; lateral process elongate, bifid, dorsal branch short, wide, ventral branch long, widest basally, dorsal branch with 1 apical spine, ventral branch with 1 mesal and 2 subapical spines; without basomesal process.

Type material. Holotype: Male, Brazil: Minas Gerais: Rio Paraúna, 3 km S Santana do Riacho,

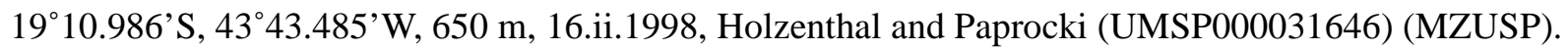

Etymology. Named for the absence of the intermediate appendage.

\section{Austrotinodes belchioris, new species}

Fig. 2

Diagnosis. This species is most similar to A. taquaralis, new species, and A. abrachium, new species. In A. belchioris, the intermediate appendage is bifid basally with a dorsal branch and a basoventral branch. In $A$. taquaralis, the basoventral branch is lacking; in A. abrachium the intermediate appendage is lacking. Additionally, in A. belchioris, the ventral and dorsal branches of the lateral process of the phallus are more equal in length than in $A$. taquaralis. 


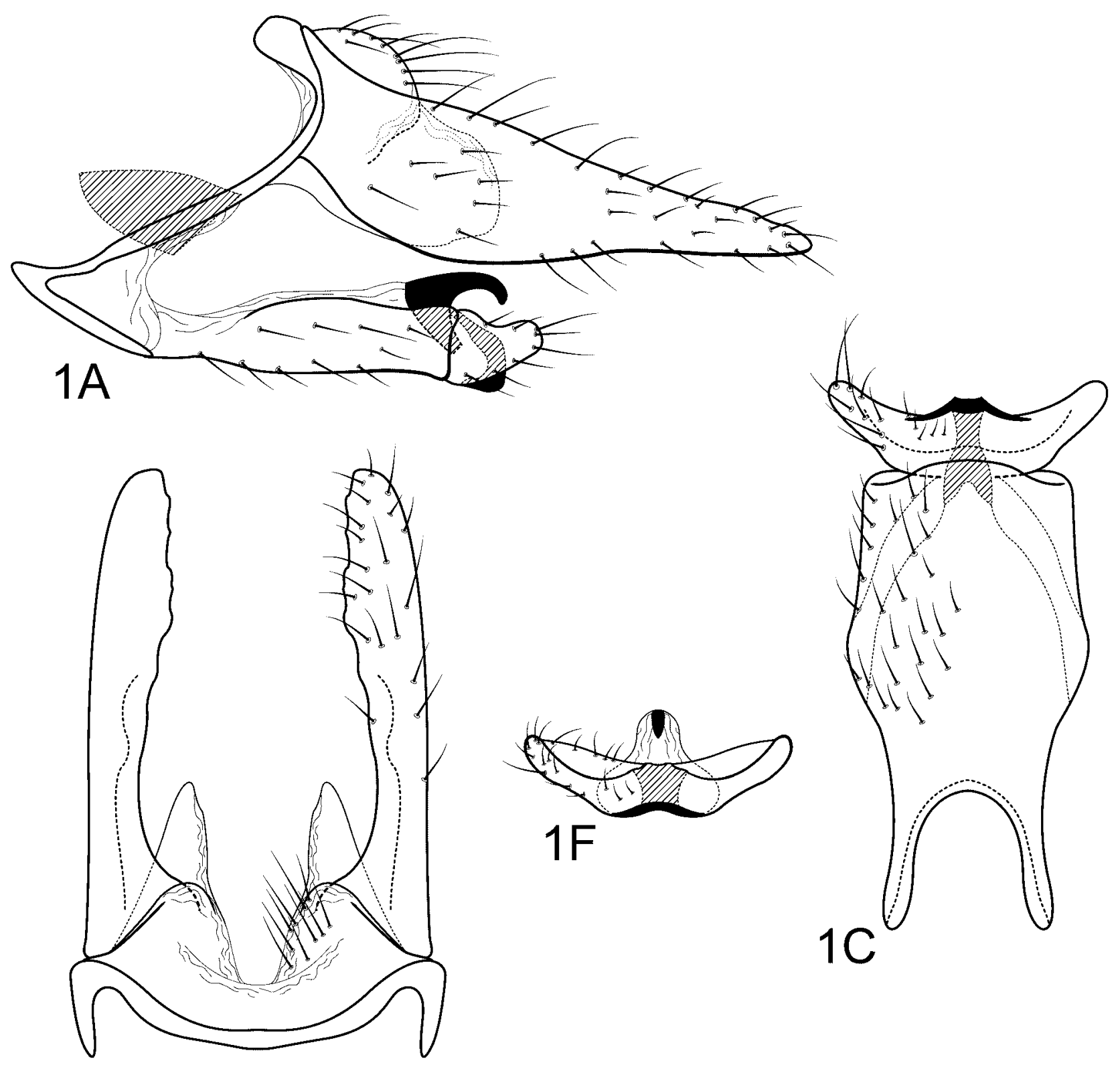

1B
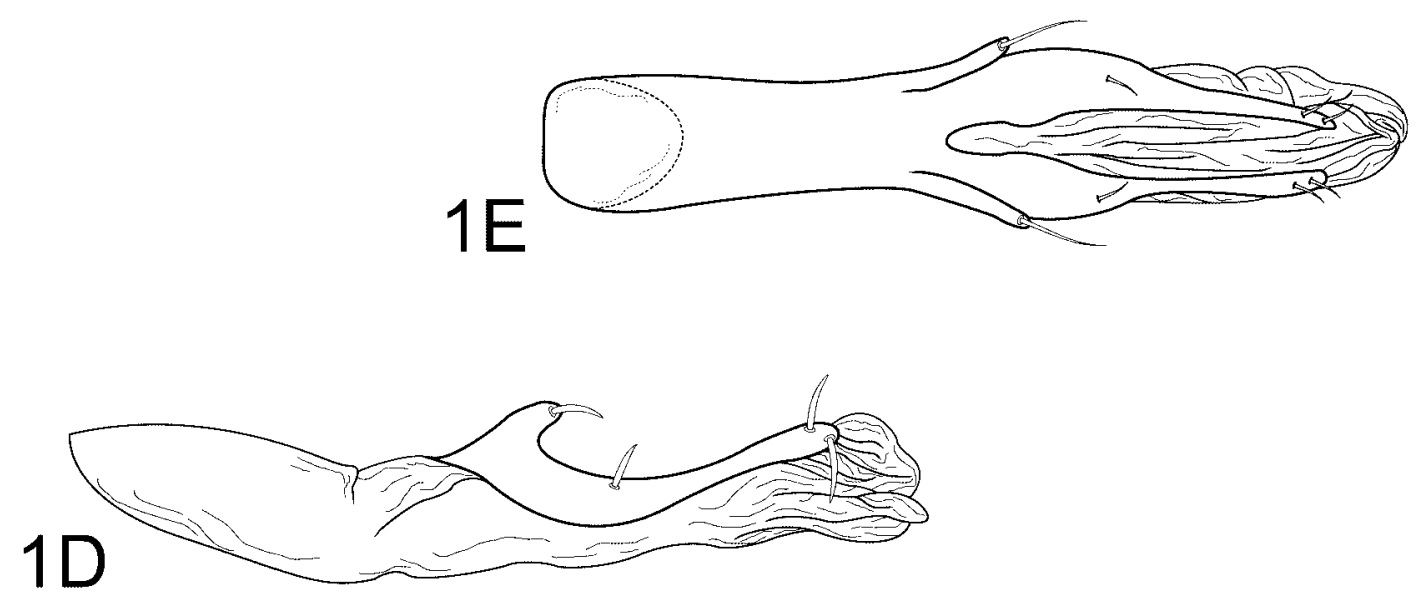

FIGURE 1. Male genitalia of Austrotinodes abrachium, new species: A, left lateral. B, dorsal. C, ventral. D, phallus, left lateral. E, phallus, dorsal. F, inferior appendage and phallic guide, caudal. 


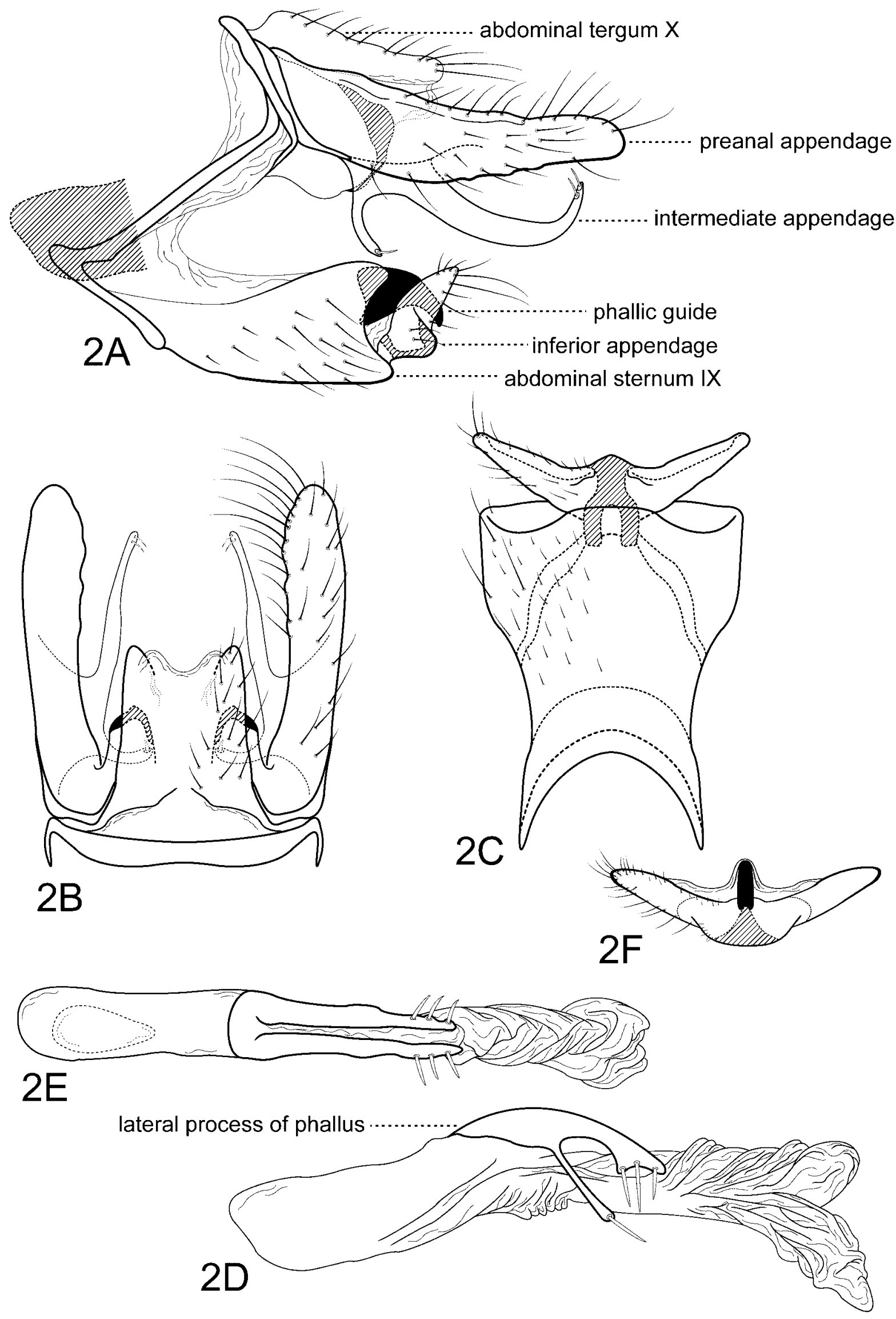

FIGURE 2. Male genitalia of Austrotinodes belchioris, new species: A, left lateral. B, dorsal. C, ventral. D, phallus, left lateral. E, phallus, dorsal. F, inferior appendage and phallic guide, caudal. 
Description. Male. Forewing length 4.7-4.9 mm ( $\mathrm{n}=5)$. Body sclerites brown, dorsum of head dark brown with pale yellow and light brown setae; thorax dark brown with pale yellow setae dorsally, light brown ventrally; leg segments with brown setae. Forewings covered with fine light brown and pale yellow setae in a mottled pattern. Genitalia. Segment IX deeply divided, sternum elongated; in lateral view, enlarging apically, ventral margin slightly convex; in ventral view, apical margin convex. Phallic guide sclerotized, not highly elevated; in lateral view, base broad, apex pointed, reaching tip of inferior appendage; in caudal view, with single indentation. Inferior appendages fused mesally, attached subapicomesally on sternum IX; in lateral view, narrowly ovate, apex acute; in ventral view, lateral lobes elongate, narrow, directed posterolaterally, posterior margin concave with central point. Tergum $\mathrm{X}$ divided into pair of semimembranous oval lobes, separated by shallow emargination, bearing dorsal setae. Preanal appendage long, surface setose, margin crenulated, parallel-sided, curving dorsally, apex narrowly rounded. Intermediate appendage long, approximately $3 / 4$ length of preanal appendage; in lateral view, straight; bifid basally, with long, curved dorsal branch and curved basoventral branch; dorsal branch bearing 2 long subapical setae, basoventral branch with 1 long apical seta. Phallus with lightly sclerotized phallobase and membranous apical region; lateral process elongate, bifid, dorsal branch widest subapically, ventral branch narrow, branches subequal, dorsal branch with row of 2 subapical and 1 apical spines, ventral branch with 1 apical spine; without basomesal process.

Type material. Holotype: Male, Brazil: Minas Gerais: Parque Estadual do Itacolomi, Córrego Belchior, 2025.048'S, 4325.737'W, 24.i.1999, Amarante (UMSP000047058) (MZUSP). Paratypes: same as holotype, 3 males, 4 females (UMSP); Brazil: Minas Gerais: Parque Estadual do Itacolomi, Rio Belchior, 2025.041'S, $43^{\circ} 25.633^{\prime} \mathrm{W}, 725$ m, 2.ii.1998, Holzenthal and Paprocki, 1 male (MZUSP).

Etymology. Named for Córrego Belchior, the stream where the holotype was collected.

\section{Austrotinodes boliviensis, new species}

Fig. 3

Diagnosis. This species is most similar to A. panamensis Flint, A. sedmani Flint, and A. texensis Bowles, but differs in the shape of the intermediate appendage. In A. boliviensis, the intermediate appendage is long and tubular with a medial quadrate projection at midlength that is absent in both A. panamensis and A. sedmani and more rounded in A. texensis. Additionally, the apical margin of the intermediate appendage of $A$. boliviensis is deeply emarginated, while the margin of A. panamensis and A. texensis is more shallowly emarginated. A shallow emargination may or may not be present in A. sedmani, due to some variation.

Description. Male. Forewing length 3.9-4.6 mm (n=8). Body sclerites brown, dorsum of head dark brown with pale yellow and dark brown setae; thorax light brown with pale yellow setae dorsally, light brown ventrally; leg segments with brown setae. Forewings covered with fine pale yellow setae with small scattered patches of light brown setae. Genitalia. Segment IX deeply divided, sternum elongated; in lateral view, enlarging apically, ventral margin slightly curved apically; in ventral view, apical margin convex. Phallic guide sclerotized, not highly elevated; in lateral view, base narrow, apex rounded, reaching middle of inferior appendage; in caudal view, with single indentation. Inferior appendages fused mesally, attached apicomesally on sternum IX; in lateral view, ovate, apex subacute; in ventral view, lateral lobes subtriangular, directed posterolaterally, posterior margin broadly concave. Tergum X divided into pair of semimembranous oval lobes, lobes bulbous, bearing row of setae dorsally. Preanal appendage long, surface setose, margin crenulated, widest basally, narrowing apically, apex narrowly rounded. Intermediate appendage long, approximately the length of preanal appendage; in lateral view, gently curved; bifid apically, with medial quadrate projection at midlength; longer lateral branch bearing 1 long apical seta, shorter mesal branch bearing 2 long subapical setae. Phallus with sclerotized phallobase and membranous apical region; lateral process short, with 3 narrow projections, each ca. 1/2 length of the following projection, each projection with 1 apical spine; without basomesal process. 

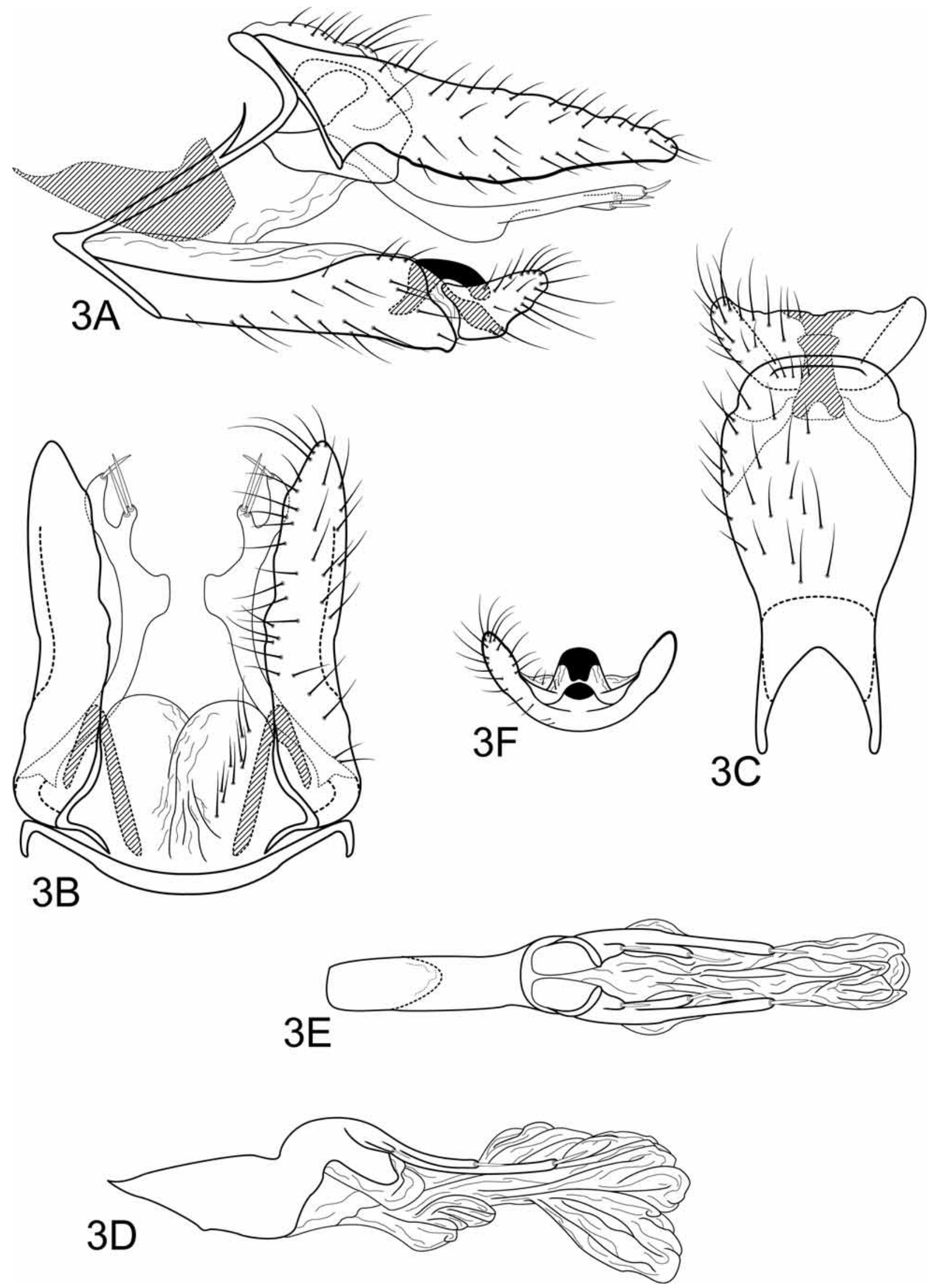

FIGURE 3. Male genitalia of Austrotinodes boliviensis, new species: A, left lateral. B, dorsal. C, ventral. D, phallus, left lateral. E, phallus, dorsal. F, inferior appendage and phallic guide, caudal. 

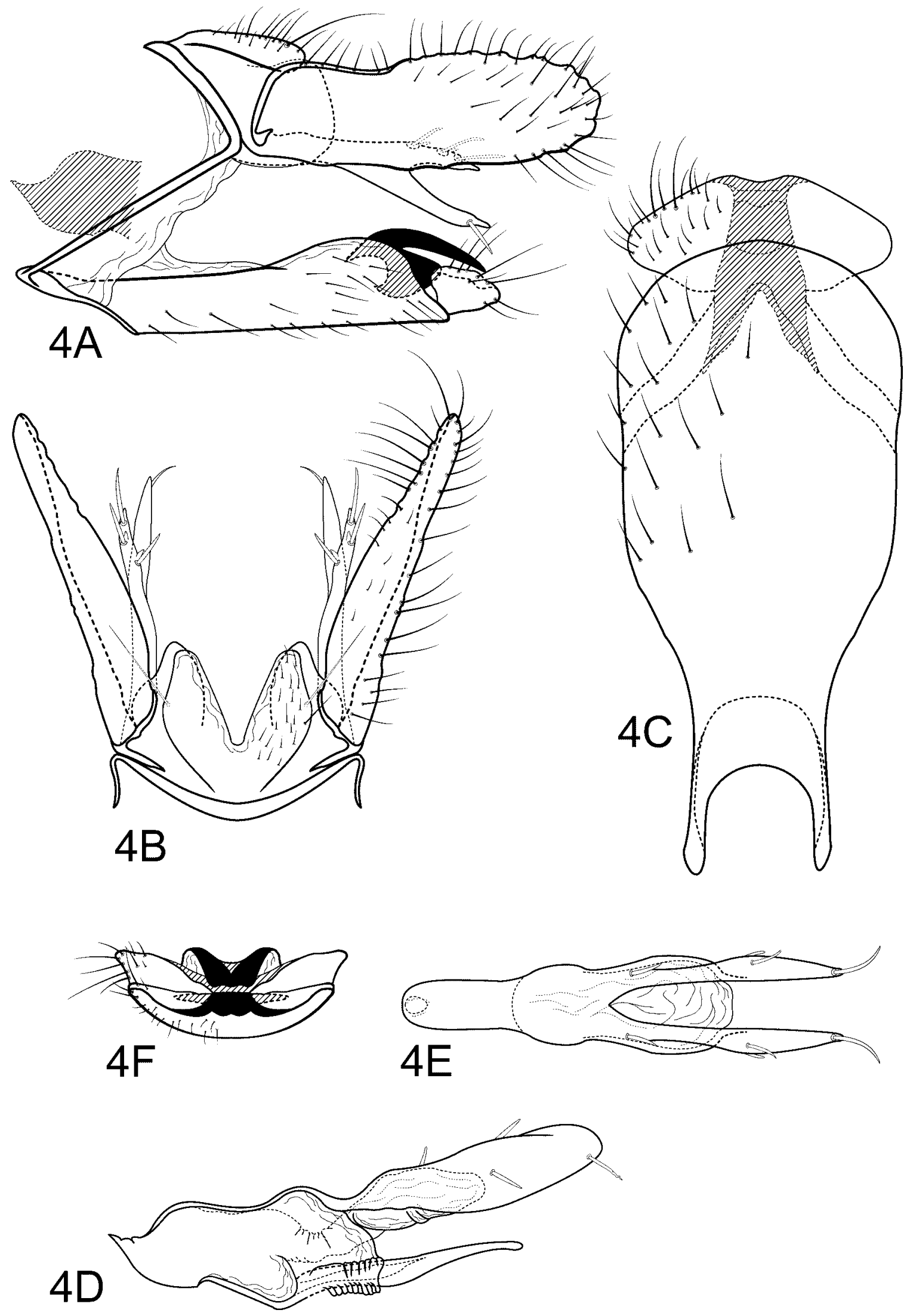

FIGURE 4. Male genitalia of Austrotinodes cressae, new species: A, left lateral. B, dorsal. C, ventral. D, phallus, left lateral. E, phallus, dorsal. F, inferior appendage and phallic guide, caudal. 
Type material. Holotype: Male, Bolivia: Dept. La Paz: AMNI Madidi, Comun. San Miguel de Bala, Arroyo Bacuatra Grande, $14^{\circ} 30.737^{\prime} \mathrm{S}, 67^{\circ} 31.385^{\prime} \mathrm{W}, 280 \mathrm{~m}, 17-19 . v i i .2003$, Robertson, Blahnik, and Apaza (UMSP000113033) (UASC). Paratypes: Bolivia: Dept. La Paz: San Buenaventura-Ixiamas Rd. km 23, Hacienda Chiquitos, Arroyo Chiquitos, $14^{\circ} 20.082^{\prime}$ S, 6 $67^{\circ} 42.204^{\prime} \mathrm{W}, 283$ m, 13-14.vii.2003, Robertson and Blahnik, 7 males, 4 females (UMSP, NMNH).

Etymology. Named for the country of Bolivia, where the specimens were collected.

\section{Austrotinodes cressae, new species}

Fig. 4

Diagnosis. This species is closest to A. amazonensis Flint and Denning and A. ariasi Flint and Denning, differing from those species in the shape and setation of the lateral process of the phallus. In A. cressae, the lateral process has 1 basal, 2 mesolateral, and 1 subapical spines and is wide in lateral view, while in $A$. amazonensis and A. ariasi the lateral process has only 1 apical seta and is slender. The basomesal process of the phallus of $A$. cressae lacks spines. Additionally, in lateral view, the dorsal margin of the intermediate appendage of $A$. cressae is straight, while the margin of A. amazonensis and A. ariasi is curved.

Description. Male. Forewing length 4.1-4.3 mm (n=2). Body sclerites brown, dorsum of head dark brown with pale yellow and light brown setae; thorax light brown with pale yellow setae dorsally, light brown ventrally; leg segments with brown setae. Forewings covered with fine light brown setae with small patches of dark brown setae along costal margin. Genitalia. Segment IX deeply divided, sternum elongated; in lateral view, enlarging apically, ventral margin straight; in ventral view, apical margin broadly convex. Phallic guide sclerotized, elevated over inferior appendages; in lateral view, base narrow, apex sharply pointed, nearly reaching tip of inferior appendage; in caudal view, with double indentation. Inferior appendages fused mesally, attached subapicomesally on sternum IX; in lateral view, ovate; in ventral view, lateral lobes triangular, directed laterally, posterior margin convex with shallow mesal emargination. Tergum $\mathrm{X}$ divided into pair of semimembranous oval lobes, separated by deep emargination, bearing slender setae and 1 prominent long seta dorsally. Preanal appendage long, surface setose, margin crenulated, parallel-sided, apex broadly rounded. Intermediate appendage short, ca. 2/3rd length of the preanal appendage; in lateral view, straight; bifid apically; dorsal branch bearing 3 large spinelike subapical setae with small adjacent projections, ventral branch bearing 1 large subapical seta. Phallus with sclerotized phallobase and membranous apical region; lateral process elongate oval, with 1 basal, 2 mesolateral, and 1 subapical spines; with elongate, narrow basomesal process.

Type material. Holotype: Male, Venezuela: Sucre: Península de Paria, Puerto Viejo, "Rio el Pozo, $10^{\circ} 43.073$ 'N, 62 $28.569^{\prime} \mathrm{W}, 20 \mathrm{~m}$, 3.iv.1995, Holzenthal, Flint, and Cressa (UMSP000041279) (UMSP). Paratypes: same as holotype, 1 female; Venezuela: Guárico: P. N. Guatopo, 0.5 km N Est. La Colina, $600 \mathrm{~m}$, $10.014^{\circ} \mathrm{N}, 66.363^{\circ} \mathrm{W}, 22.1 .1994$, Holenthal, Cressa, and Rincón, 1 male (UMSP); Sucre: Parque Nac. Península de Paria, Uquire, R. La Viuda 1042.830'N, 61⒌661'W, 15 m, 30.iii-1.iv.1995, Holzenthal, Flint, and Cressa, 1 female (UMSP); Península de Paria, Santa Isabel, Rio Sta. Isabel, 1044.294'N, 62³8.954'W, 20 m, 4.iv.1995, Holzenthal, Flint, and Cressa, 1 female (UMSP).

Etymology. Named in honor of Dr. Claudia Cressa, an aquatic ecologist at the Universidad Central de Venezuela and friend and colleague of the authors.

\section{Austrotinodes longispinum, new species}

Fig. 5

Diagnosis. This species is closest to A. prolixus Flint and Denning, differing in the shape and setation of the lateral process of the phallus. In A. longispinum, the lateral process is widest mesally while in A. prolixus it is widest basally. The lateral process of $A$. longispinum bears 1 elongate mesolateral spine and 1 small apical spine. The lateral process of A. prolixus bears 1 slender and 2 enlarged mesolateral spines and 1 enlarged 

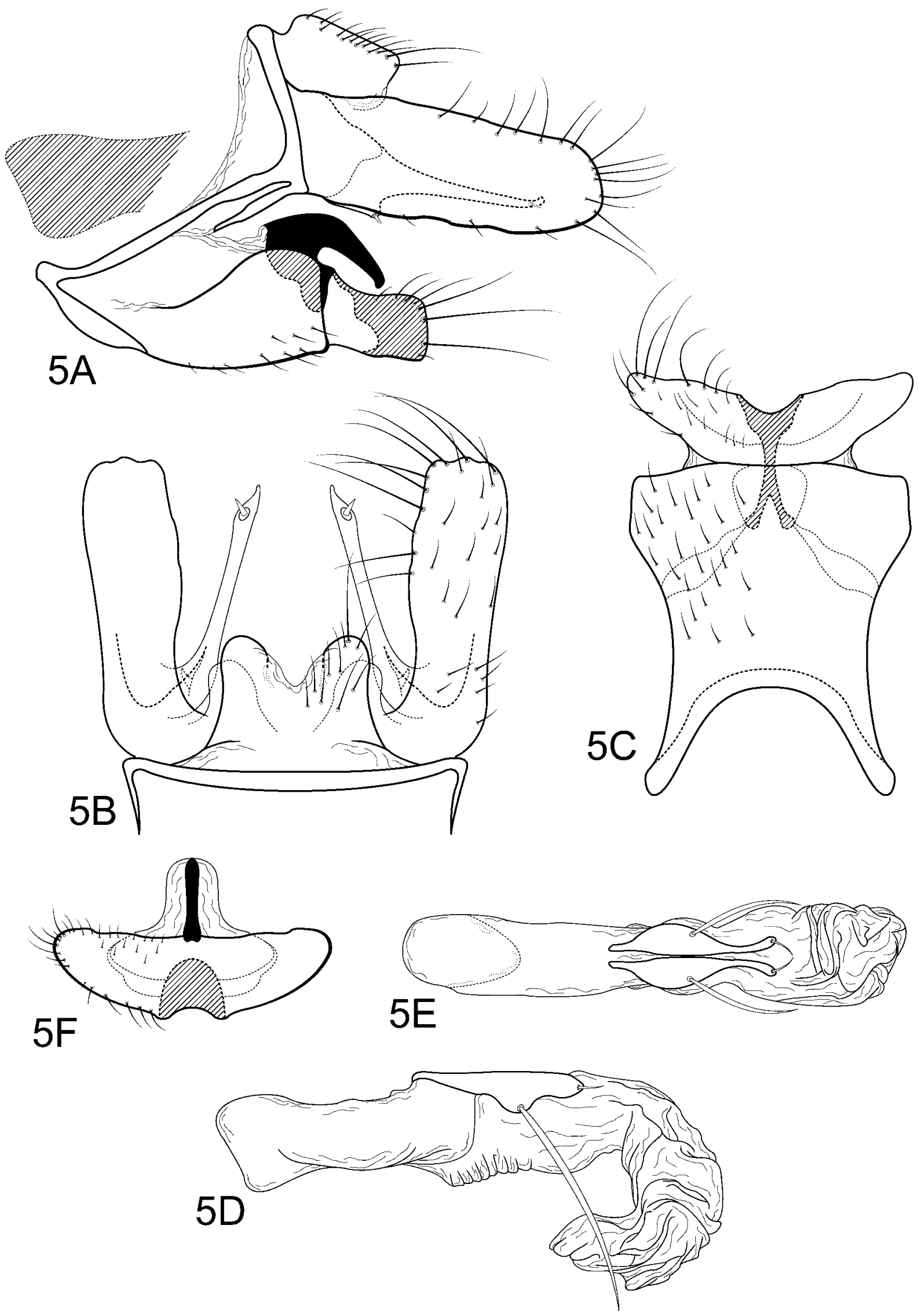

FIGURE 5. Male genitalia of Austrotinodes longispinum, new species: A, left lateral. B, dorsal. C, ventral. D, phallus, left lateral. E, phallus, dorsal. F, inferior appendage and phallic guide, caudal. 
apical spine. Additionally, the phallus of A. longispinum has a more extensive apical membranous region than that of A. prolixus.

Description. Male. Forewing length 4.6-5.2 mm (n=3). Body sclerites brown, dorsum of head dark brown with pale yellow and dark brown setae; thorax dark brown with pale yellow and dark brown setae dorsally, light brown ventrally; leg segments with brown setae. Forewings covered with fine light brown setae with small scattered patches of pale yellow setae. Genitalia. Segment IX deeply divided, sternum elongated; in lateral view, enlarging apically, ventral margin slightly convex; in ventral view, apical margin convex. Phallic guide sclerotized, elevated over inferior appendages; in lateral view, base broad, apex hooked, reaching middle of inferior appendage; in caudal view, with single indentation. Inferior appendages fused mesally, attached apicomesally on sternum IX; in lateral view, quadrate, apex truncate; in ventral view, lateral lobes triangular, directed posterolaterally, posterior margin with mesal emargination. Tergum X divided into pair of semimembranous oval lobes, separated by shallow emargination, bearing dorsal setae. Preanal appendage long, surface setose, margin crenulated, parallel-sided, apex broadly rounded. Intermediate appendage long, approximately 3/4 length of preanal appendage; in lateral view, straight; bifid basally, with long, straight dorsal branch and very short basoventral branch; dorsal branch bearing 1 short subapical seta, short basoventral branch with 1 short apical seta. Phallus with lightly sclerotized phallobase and membranous apical region; lateral process short, elongate oval, widest mesally, with 1 very elongate, mesolateral spine, and 1 small apical spine; without basomesal process.

Type material. Holotype: Male, Brazil: São Paulo: Cachoeira do Paredão, Lajeado, Serra da Bocaina, $22^{\circ} 43.533^{\prime} \mathrm{S}, 4^{\circ} 37.274^{\prime} \mathrm{W}, 1550 \mathrm{~m}, 1-2 . i i i .2002$, Holzenthal, Blahnik, Paprocki, and Prather (UMSP000088117) (MZUSP). Paratypes: same as holotype, 1 male, 1 female (UMSP); Rio de Janeiro: P. N. da Serra dos Órgãos, Rio Beija-flor, 22 27.063'S, 43ํ0.065'W, 1125 m, 27.ii.2002, Holzenthal, Blahnik, Paprocki, and Prather, 1 male (UMSP).

Etymology. Named for the elongate mesolateral spine observed on the phallus.

\section{Austrotinodes taquaralis, new species}

Fig. 6

Diagnosis. This species is most similar to A. belchioris, new species, and A. abrachium, new species. In A. taquaralis, the intermediate appendage is lacking the basoventral branch of $A$. belchioris but has instead a single basoventral seta. While the dorsal branch of the intermediate appendage in A. belchioris has 2 setae, there are 3-4 present in A. taquaralis. Additionally, in A. taquaralis, the membranous apical region of the phallus is shorter in proportion to the lateral process than in A. belchioris or A. abrachium.

Description. Male. Forewing length 4.9-5.3 mm (n=6). Body sclerites brown, dorsum of head light brown with pale yellow and light brown setae; thorax light brown with pale yellow setae dorsally, light brown ventrally; leg segments with brown setae. Forewings covered with fine dark brown and pale yellow setae in a mottled pattern. Genitalia. Segment IX deeply divided, sternum elongated; in lateral view, enlarging apically, ventral margin slightly convex; in ventral view, apical margin convex. Phallic guide sclerotized, not highly elevated; in lateral view, base narrow, apex pointed, reaching tip of inferior appendage; in caudal view, with single indentation. Inferior appendages fused mesally, attached apicomesally on sternum IX; in lateral view, ovate; in ventral view, lateral lobes subquadrate, directed posterolaterally, posterior margin concave with central point. Tergum X divided into pair of semimembranous oval lobes, lobes bulbous, bearing dorsal setae. Preanal appendage long, surface setose, margin crenulated, parallel-sided, apex rounded. Intermediate appendage long, approximately 3/4 length of preanal appendage; in lateral view, curved; single; bearing 3-4 large spinelike setae apically and 1 seta basoventrally. Phallus with sclerotized phallobase and membranous apical region; lateral process elongate, bifid, dorsal branch long, wide, ventral branch short, narrow, dorsal branch with row of 2 subapical and 1 apical spines, ventral branch with 1 apical spine; without basomesal process. 


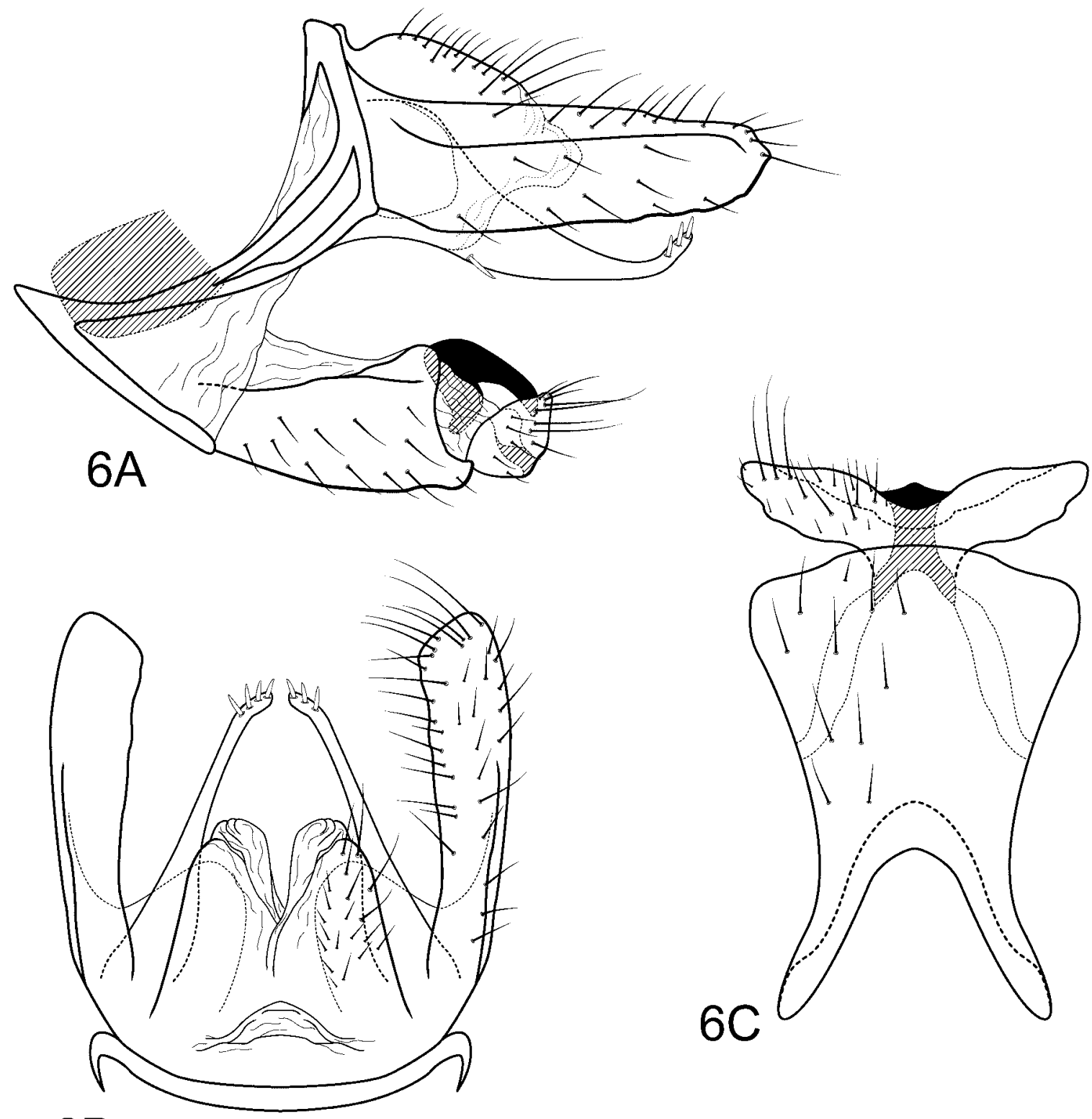

$6 \mathrm{~B}$
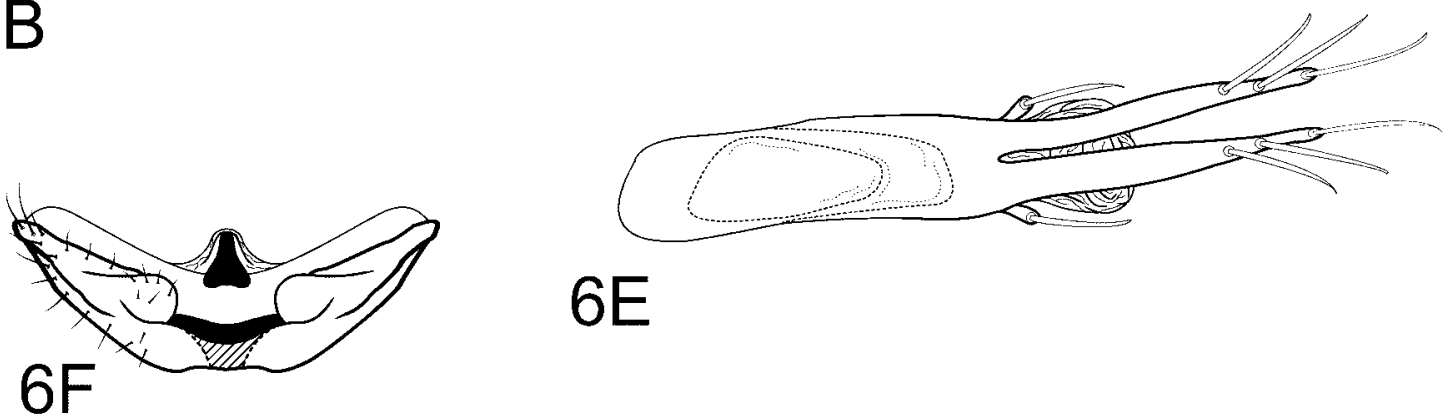

$6 \mathrm{E}$

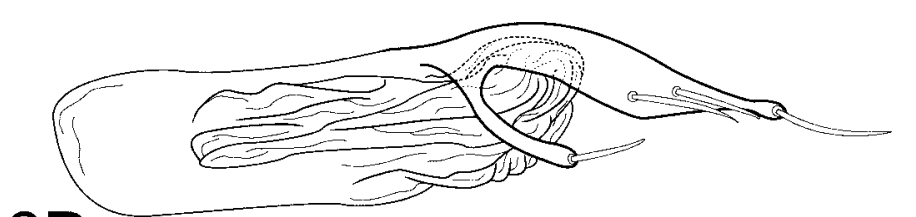

6D

FIGURE 6. Male genitalia of Austrotinodes taquaralis, new species: A, left lateral. B, dorsal. C, ventral. D, phallus, left lateral. E, phallus, dorsal. F, inferior appendage and phallic guide, caudal. 
Type material. Holotype: Male, Brazil: Rio de Janeiro: Parque Nacional Itatiaia, Rio Taquaral,

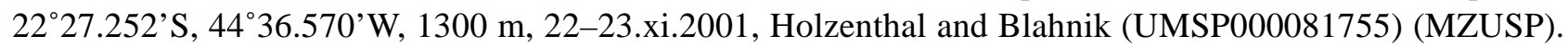
Paratypes: same as holotype, 2 females (UMSP); Brazil: Minas Gerais: Aldeia da Cachoeira das Pedras, 2006.824'S, 44 01.412'W, 925 m, 28-29.ix.2000, Paprocki and Braga, 1 male, 3 females (MZUSP); Parque

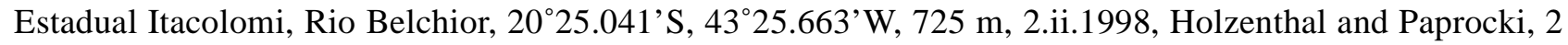
males, 12 females (UMSP); Estação Ecológica de Tripu, Córrego Botafoga, 20²2.908' S, 43³3.615'W, 1100 m, 1.ii.1998, Holzenthal and Paprocki, 1 male (UMSP); Cachoeira do Abacaxi, Vale de Tropeiro, Ouro Preto, $20^{\circ} 12.270^{\prime} \mathrm{S}, 43^{\circ} 38.163^{\prime} \mathrm{W}, 1120$ m, 7.xi.2001, Paprocki, Blahnik, and Amarante, 1 male (NMNH).

Etymology. Named for Rio Taquaral, the river where the holotype was collected.

\section{Acknowledgements}

We are grateful to Desiree R. Robertson for permission to describe the new species collected during her research project in Bolivia. For assistance in the field, we are especially thankful to H. Paprocki, R. Blahnik, M. Amarante, O.S. Flint, Jr., J. Rincón, A. Prather, and V. Braga. We thank Dr. John Morse, Dr. David Cartwright, and an anonymous reviewer for their helpful and expeditious reviews of the manuscript. This material is based on work supported by the National Science Foundation grant nos. DEB 9971885, 0117772, and 0816865 .

\section{References}

Angrisano, E.B. (1994) Contribución al conocimiento de los Trichoptera del Uruguay. I. Familias Ecnomidae y Polycentropodidae. Revista de la Sociedad Entomologica Argentina, 53, 129-139.

Blahnik, R.J., Holzenthal, R.W. and Prather, A. (2007) The lactic acid method for clearing Trichoptera genitalia. In, J. Bueno-Soria, R. Barba-Alvarez, and B. Armitage (Eds), Proceedings of the XIIth International Symposium on Trichoptera. The Caddis Press, Columbus, Ohio, pp. 9-14.

Botosaneanu, L. (1990) Results of a Trichopterological (Insecta: Trichoptera) travel to the Lesser Antilles in 1989. Bulletin de l'Institute Royal des Sciences Naturelles de Belgique, Entomologie, 60, 39-48.

Bowles, D.E. (1995) A new species of Austrotinodes (Trichoptera: Ecnomidae) from Texas. Journal of New York Entomological Society, 103, 155-161.

Cartwright, D.I. (2009) Austrotinodes Schmid, a South and Central American caddisfly genus, newly recorded in Australia, with the description of new species (Trichoptera: Ecnomidae). Zootaxa, 2142, 1-19.

Dallwitz, M.J., Paine, T.A. and Zurcher, E.J. (1999 onwards) User's guide to the DELTA editor. Available from: http:// delta-intkey.com/ (accessed 1 February 2010).

Flint, O.S., Jr. (1969) Studies of Neotropical caddis flies IX: new genera and species from the Chilean subregion (Trichoptera). Proceedings of the Biological Society of Washington, 71, 497-514.

Flint, O.S., Jr. (1973) Studies of Neotropical caddisflies, XVI: the genus Austrotinodes (Trichoptera: Psychomiidae). Proceedings of the Biological Society of Washington, 86, 127-142.

Flint, O.S., Jr. (1983) Studies of Neotropical caddisflies, XXXIII: new species from austral South America (Trichoptera). Smithsonian Contributions to Zoology, 377, 1-100.

Flint, O.S., Jr. (1996) Studies of Neotropical caddisflies LV: Trichoptera of Trinidad and Tobago. Transactions of the American Entomological Society, 122, 67-112.

Flint, O.S., Jr. and Denning, D.G. (1989) Studies of Neotropical caddisflies XLI: New species and records of Austrotinodes (Trichoptera: Psychomyiidae). Pan Pacific Entomologist, 65, 108-122.

Flint, O.S., Jr., Holzenthal, R.W. and Harris, S.C. (1999) Catalog of the Neotropical Caddisflies (Insecta: Trichoptera). A Special Publication of the Ohio Biological Survey, Columbus, Ohio, $239 \mathrm{pp}$.

Flint, O.S., Jr. and Sykora, J.L. (2004) Caddisflies of Hispaniola, with special reference to the Dominican Republic (Insecta: Trichoptera). Annals of Carnegie Museum, 73, 1-60.

Holzenthal, R.W. and Andersen, T. (2004) The caddisfly genus Triaenodes in the Neotropics (Trichoptera: Leptoceridae). Zootaxa, 511, 1-80.

Johanson, K.A. and Espeland, M. (2009) Phylogeny of the Ecnomidae (Insecta: Trichoptera). Cladistics, 25, 1-13.

Kumanski, K.P. (1987) On caddisflies (Trichoptera) of Cuba. Acta Zoologica Bulgarica, 34, 3-35. 
Muñoz-Quesada, F. and Holzenthal, R.W. (1993) New species and records of Costa Rican Austrotinodes (Trichoptera: Ecnomidae). Proceedings of the Entomological Society of Washington, 95, 564-573.

Navás, L. (1934) Insectos Suramericanos, novena serie. Revista de la Academia de Ciencias de Madrid, 31, $155-184$.

Schmid, F. (1955) Contribution la connaissance des Trichoptères néotropicaux. Mémoires de la Sociét vaudoise des Sciences Naturelles, 11, 117-160.

Schmid, F. (1958) Contribution la l'étude des Trichoptères néotropicaux III. Mitteilungen aus dem Zoologischen Museum in Berlin, 34, 183-217.

Schmid, F. (1964) Contribution la l'étude des Trichoptères néotropicaux V. Tidjschrift, voor Entomologie, 107, $307-339$.

Wiggins, G.B. (1996) Larvae of the North American Caddisfly Genera (Trichoptera), Second Edition. University of Toronto Press, Toronto, 457 pp. 